http://revistas.ucr.ac.cr/index.php/ingenieria www.ucr.ac.cr / ISSN 1409-2441
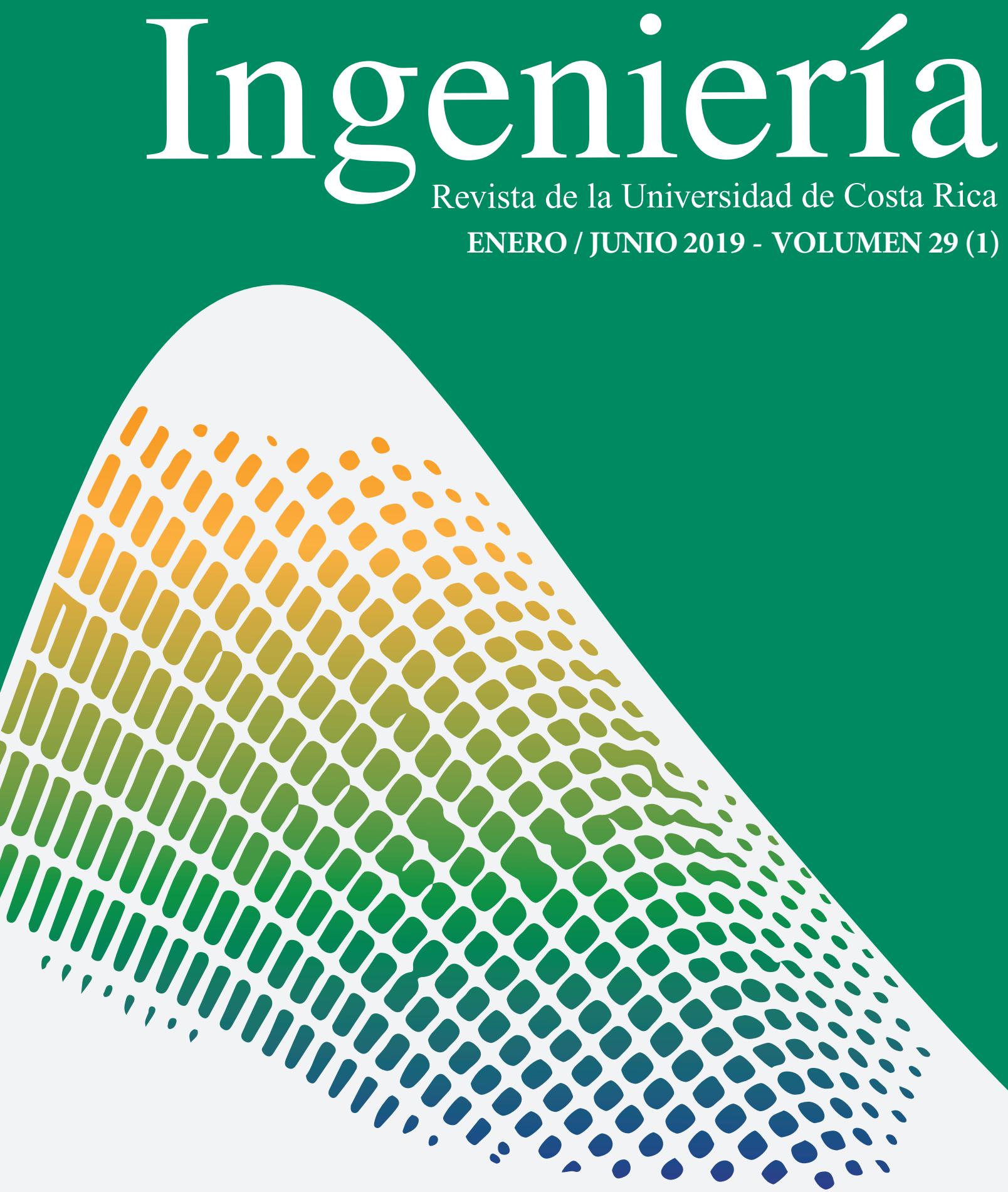


\title{
Statistical optimization of lactic acid production by Lactobacillus pentosus using hemicellulose hydrolysate from sugarcane bagasse
}

\author{
Optimización estadística de la producción de ácido láctico \\ mediante Lactobacillus pentosus usando hidrolizado \\ hemicelulósico proveniente de bagazo de caña de azúcar
}

\author{
Daiana Wischral \\ Federal University of Rio de Janeiro, Brasil. Laboratories of Bioprocess \\ Development, School of Chemistry, Department of Biochemical Engineering \\ daianawischral@gmail.com \\ Johanna Méndez Arias \\ Universidad de Costa Rica, Costa Rica. Instituto de Investigaciones en Ingeniería, \\ Escuela Ingeniería Industrial \\ Nei Pereira Jr \\ Federal University of Rio de Janeiro, Brasil. Laboratories of Bioprocess \\ Development, School of Chemistry, Department of Biochemical Engineering
}

Recibido: 31 de mayo 2018

Aceptado: 17 de octubre 2018

\begin{abstract}
The present work reports investigation of hemicellulose hydrolysate from sugarcane bagasse as a sole carbon source for lactic acid production by Lactobacillus pentosus ATCC 8041. Initially, sugarcane bagasse was pretreated with acid in a solid:liquid ratio of 1:2.8 (1 $\mathrm{g}$ of bagasse: $2.8 \mathrm{~mL}$ of sulfuric acid solution $1 \% \mathrm{v} / \mathrm{v}$ ) at a temperature of $121^{\circ} \mathrm{C}$ for $27 \mathrm{~min}$. Then, concentration of both the hemicellulose hydrolysate and the yeast extract in MRS medium were optimized using Response Surface Methodology through software STATISTICA 6.0. Once the optimal conditions ( $40 \%$ of hemicellulose hydrolysate and $5 \mathrm{~g} / \mathrm{L}$ of yeast extract) were validated, fermentations were carried out in anaerobic conditions at $37^{\circ} \mathrm{C}$ and $120 \mathrm{rpm}$. After $48 \mathrm{~h}, 19.17 \mathrm{~g} / \mathrm{L}$ of lactic acid were produced, with yield of $0.80 \mathrm{~g} / \mathrm{g}$, corresponding to a volumetric productivity $0.40 \mathrm{~g} /(\mathrm{L} \cdot \mathrm{h})$ Findings of this work demonstrate that hemicellulose hydrolysate from sugarcane bagasse is a promising carbon source for lactic acid production.
\end{abstract}

Keywords:

Lignocellulosic biomass, acid pretreatment, Lactobacillus pentosus ATCC 8041, lactic acid, statistical optimization. 


\section{Resumen}

El presente trabajo reporta la investigación del uso de hidrolizado hemicelulósico, proveniente de bagazo de caña de azúcar, como única fuente de carbono para la producción de ácido láctico mediante Lactobacillus pentosus ATCC 8041. Inicialmente, el bagazo de caña fue pretratado con ácido en una relación sólido líquido de 1:2.8 (1 g de bagazo: $2.8 \mathrm{~mL}$ de ácido sulfúrico al 1 $\%$ v/v) y a una temperatura de $121^{\circ} \mathrm{C}$ por $27 \mathrm{~min}$. Luego, tanto la concentración del hidrolizado hemicelulósico como del extracto de levadura en medio MRS fueron optimizadas empleando Metodología de Superficie de Respuesta mediante el software STATISTICA 6.0. Una vez que las condiciones óptimas fueron validadas ( $40 \%$ de hidrolizado hemicelulósico y $5 \mathrm{~g} / \mathrm{L}$ de extracto de levadura), se realizaron fermentaciones en condiciones anaeróbicas a $37^{\circ} \mathrm{C}$ y $120 \mathrm{rpm}$. Después de $48 \mathrm{~h}$ se produjeron $19.17 \mathrm{~g} / \mathrm{L}$ de ácido láctico, rendimiento de $0.80 \mathrm{~g} / \mathrm{g}$, correspondientes a una productividad volumétrica de $0.40 \mathrm{~g} /(\mathrm{L} \cdot \mathrm{h})$. Los resultados de este trabajo demuestran que el hidrolizado hemicelulósico de bagazo de caña de azúcar es una fuente de carbono prometedora para la producción de ácido láctico.

\section{Palabras clave:}

Biomasa lignocelulósica, pretratamiento ácido, Lactobacillus pentosus ATCC8041, ácido láctico, optimización estadística. 


\section{INTRODUCTION}

Lignocellulosic materials are a natural and renewable source of feedstock that can be used for production of more value-added products. However, prior to their use, these materials must be deconstructed in its main components (cellulose, hemicellulose and lignin) in a step known as pretreatment. Thus, pretreatment can be physical, chemical, biological, or a combination of them (Hendriks \& Zeeman, 2009; Kumar, Barrett, Delwiche, \& Stroeve, 2009; Amin et al. 2017; Liu et al., 2018).

When lignocellulosic materials undergo through acid pretreatment, which uses dilute acid, a fraction rich in xylose, named hemicellulose hydrolysate $(\mathrm{HH})$, is obtained. However, despite being a monosaccharide, xylose fermentation is more difficult when compared to glucose's, since fewer microorganisms have the ability to assimilate it. Another obstacle concerning use of hemicellulose hydrolysate is related to the presence of metabolic inhibitors, such as furfural, 5-hydroxymethylfurfural (HMF) and acetic acid, which are formed during pretreatment (Deshavath et al., 2017; Kumar, Barrett, Delwiche, \& Stroeve, 2009; Gonzales, Sivagurunathan, \& Kim, 2016) use of HH, and its further conversion to value-added products, is the objective of many researches in the area.

The valorization of lignocellulosic agrowastes as well as food industry by-products for production of lactic acid will solve their disposal problem, environmental issues and eliminate dependence on petrochemical compounds (Pejin et al. 2018). Lactic acid presents numerous applications in food, pharmaceutical, and textile industry. Moreover, it is widely used for production of biodegradable plastics. Traditionally, it is obtained through glucose fermentation using Lactobacillus sp bacteria, which, in their majority, are not able to assimilate pentoses. Likewise, the use of hemicellulose hydrolysate still requires additional studies for better understanding how its composition affects fermentation, since interaction between microorganism and carbon source is one of the main factors to be studied while aiming at a feasible process (Garde, Jonsson, Schmidt, \& Ahring, 2002; Patel, Ou, Ingram, \& Shanmugam, 2004; Abdel-Rahman, Tashiro, \& Sonomoto, 2011; Es et al., 2018).

According to De Oliveira, Komesu, Rossell \& Maciel Filho, (2018), the xylose assimilation pathways allowing pentose sugars to be consumed by pentose phosphate pathway (homolactic) or phosphoketolase pathway (heterolactic). The theoretical value of the lactic acid production by pentose molecule is 1.67 in homolactic fermentations ( 3 xylose molecules to generate 5 molecules of lactic acid). In heterolactic fermentations, the theoretical value of the lactic acid production by pentose molecule is 1.00 ( 3 xylose molecules to generate 5 molecules of lactic acid and 3 molecules of acetate).

Lactic acid is an already consolidated bioproduct in the world market. It has many applications and new applications are being discovered every year, especially in chemical industries as a building-block molecule. The lactic acid market is in constant growth and the fact that the final products are able to comply with environmental laws as green, renewable and biodegradable products contributes to the tendency of continuous growth in the next few years. The global lactic acid market required $1220.0 \mathrm{kt}$ in 2016 . With 
annual growth of $16.2 \%$, it is expected that this demand will reach $1960.1 \mathrm{kt}$ in 2025 . This should represent USD 9.8 billion in the global market (De Oliveira, Komesu, Rossell \& Maciel Filho, 2018).

Hence, the present work reports the investigation of hemicellulose hydrolysate from sugarcane bagasse as the sole carbon source for lactic acid production by Lactobacillus pentosus ATCC 8041.

\section{METHODOLOGY}

\subsection{Pretreatment of biomass}

Acid pretreatment of sugarcane bagasse was performed in a solid: liquid ratio of 1:2.8 ( $1 \mathrm{~g}$ of bagasse: $2.8 \mathrm{~mL}$ of sulfuric acid solution $1 \% \mathrm{v} / \mathrm{v})$ at a temperature of $121^{\circ} \mathrm{C}$ for $27 \mathrm{~min}$, as previously described by Betancur \& Pereira Jr. (2010). After this stage, a liquid fraction, corresponding to the hemicellulose hydrolysate $(\mathrm{HH})$, was obtained. Then, this fraction had its $\mathrm{pH}$ adjusted to 6.5 (fermentation condition) through addition of $\mathrm{CaCO}_{3}$, and it was subjected to vacuum filtration.

\subsection{Strain and culture media}

Lactobacillus pentosus ATCC 8041 was obtained from American Type Culture Collection (ATCC). It was used for evaluation of both xylose consumption and lactic acid production. Culture media applied in this work were based on Man, Rogosa, Sharpe medium (MRS), traditionally used for Lactobacillus $s p$ fermentations: $10 \mathrm{~g} / \mathrm{L}$ peptone, $10 \mathrm{~g} / \mathrm{L}$ beef extract, $1 \mathrm{ml} / \mathrm{L}$ tween $80,2 \mathrm{~g} / \mathrm{L}$ ammonium citrate, $5 \mathrm{~g} / \mathrm{L}$ sodium citrate, $0.1 \mathrm{~g} / \mathrm{L} \mathrm{MgSO}_{4}, 0.05 \mathrm{~g} / \mathrm{L} \mathrm{MnSO}_{4}$ and $2 \mathrm{~g} / \mathrm{L} \mathrm{K}_{2} \mathrm{HPO}_{4}$. The amounts of $\mathrm{HH}$ and yeast extract in the culture media variated according to design experimental using Central Composite Rotatable Design (CCRD) methodology (Table 1). Fermentations were performed in $100 \mathrm{~mL}$ serum bottles, with $50 \mathrm{~mL}$ of reaction volume, at $180 \mathrm{rpm}$ during $48 \mathrm{hrs}$ and at initial $\mathrm{pH}$ of 6.5 , without $\mathrm{pH}$ control during fermentations. All of culture medium were sparged with nitrogen during $10 \mathrm{~min}$, with the purpose of achieving anaerobic conditions, and sterilized $\left(121^{\circ} \mathrm{C}\right.$ for $\left.20 \mathrm{~min}\right)$ before inoculation.

Table 1. CCRD factors and levels for optimization of hemicellulose hydrolysate and yeast extract concentrations.

\begin{tabular}{lccccc}
\hline Factor & Axial & Minimum & Central Point & Maximun & Axial \\
& -1.41 & -1 & 0 & +1 & +1.41 \\
\hline HH $(\%)(\mathrm{v} / \mathrm{v})$ & 20 & 25 & 37.5 & 50 & 55 \\
Yeast extract $(\mathrm{g} / \mathrm{L})$ & 2 & 2.5 & 3.75 & 5.0 & 5.5 \\
\hline
\end{tabular}

HH: Hemicellulose hydrolysate. 


\subsection{Optimization}

Aiming at optimization of hemicellulose hydrolysate and yeast extract concentrations in culture media, a Central Composite Rotatable Design, along with Response Surface Methodology, was applied. Main goal was to maximize lactic acid production. Experimental design and its analyses were performed using software STATISTICA, version 6.0 (StatSoft, Inc.) including ANOVA. Impact and significance of each independent variable, their interactions, as well as the response variables were analyzed. Fit quality of the polynomial model was expressed thought coefficient $\mathrm{R}^{2}$, while results concerning experimental data were evaluated for a $95 \%$ confidence interval (or p-value less than 0.05) and verified with the F-test, included in the same software. Minimum and maximum levels of the independent variables were coded as " -1 " and " +1 ", respectively, with three replicates in the central point, coded as " 0 ", and two axials points, coded "-1.41" and "+1.41", as shown in Table 1.

\subsection{Analytical methods}

Glucose, xylose, lactic acid, acetic acid, 5-hydroxymethylfurfural, cellobiose and furfural concentrations were determined by HPLC (Shimadzu) at PL Hi-Plex column $\mathrm{H} 8 \mu \mathrm{m}(300 \times 7.7 \mathrm{~mm})$, with $20 \mu \mathrm{L}$ of injection volume, and $\mathrm{H}_{2} \mathrm{SO}_{4} 0.005 \mathrm{~mol} / \mathrm{L}$ as mobile phase at $0.6 \mathrm{~mL} / \mathrm{min}, 60^{\circ} \mathrm{C}$, using RID and UV $(210 \mathrm{~nm})$ detectors. External standards were used for identification and quantification of peak areas.

\section{RESULTS AND DISCUSSION}

Composition of hemicellulose hydrolysate from sugarcane bagasse, after acid pretreatment, is shown in Table 2. Its main sugar is xylose, followed by glucose, which may come from heteropolymers that are present in the hemicellulose fraction. Due to the conditions at which this step is carried out, hydrolysis of the hemicellulose portion is favored over cellulose hydrolysis (Xavier, Coradini, Deckman, \& Franco, 2017).

Table 2. Composition of hemicellulose hydrolysate from sugarcane bagasse after acid pretreatment.

\begin{tabular}{lc}
\hline Component & Concentration $(\mathrm{g} / \mathrm{L})$ \\
\hline Glucose & $3.9 \pm 1.7$ \\
Xylose & $55.3 \pm 3.2$ \\
Cellobiose & $2.3 \pm 1.7$ \\
Acetic acid & $12.1 \pm 2.5$ \\
5-hydroxymethylfurfural (HMF) & $0.06 \pm 0.01$ \\
Furfural & $0.19 \pm 0.03$ \\
\hline
\end{tabular}


Acetic acid, furfural and HMF are also present in HH (Table 2). These substances are responsible for growth and metabolism inhibition of some microorganisms (Chandel, Singh, \& Rao, 2010; Xavier, Coradini, Deckman \& Franco, 2017). They are formed during hydrolysis of acetyl groups (acetic acid) and of pentoses and hexoses (furfural and HMF), caused by thermochemical degradation of both cellulose and hemicelluloses (Chandel, Da Silda, \& Singh et al., 2011; Xavier, Coradini, Deckman \& Franco, 2017).

Reducing levels of these toxic compounds is necessary for an efficient fermentation stage. For such, some well-known techniques are used; for example: acclimation steps, detoxification of $\mathrm{HH}$ or even metabolic and genetic engineering (Jönsson \& Martín, 2016). These procedures, however, raise process costs, making it more difficult to have feasible technologies that use lignocellulosic materials as feedstock. Industrially, microorganisms that can assimilate pentoses and tolerate inhibitors are indicated for conversion of xylose into more value-added products (Garde, Jonsson, Schmidt \& Ahring, 2002; Patel, Ou, Ingram \& Shanmugam, 2004.

Therefore, the objective of this paper is to evaluate $\mathrm{HH}$ levels (\% v/v) (carbon source) that bacteria L. pentosus ATCC 8041 can tolerate without affecting lactic acid production, nor requiring detoxification steps. Besides, paper also aims at determining optimal yeast extract concentration (nitrogen source). Since fermentation medium is rich in yeast extract (an expensive nutrient), and the main substrate $(\mathrm{HH})$ is also present in high amounts, seeking for optimal levels of both could help in improve process efficiency and reducing process costs. Table 3 displays design matrix of the experiments, along with the results of lactic acid production for each point.

Table 3. Matrix of CCRD experimental design including results for lactic acid production after $48 \mathrm{~h}$.

\begin{tabular}{lccc}
\hline Run & Hemicellulose hydrolysate & $\begin{array}{c}\text { Yeast } \\
\text { extract }\end{array}$ & $\begin{array}{c}\text { Lactic acid } \\
(\mathrm{g} / \mathrm{L})\end{array}$ \\
\hline 1 & -1 & -1 & 14.14 \\
2 & 1 & -1 & 18.72 \\
3 & -1 & 1 & 16.03 \\
4 & 1 & 1 & 18.95 \\
5 & -1.41 & 0 & 14.29 \\
6 & 1.41 & 0 & 19.45 \\
7 & 0 & -1.41 & 17.65 \\
8 & 0 & 1.41 & 18.75 \\
$9(\mathrm{CP})$ & 0 & 0 & 18.01 \\
$10(\mathrm{CP})$ & 0 & 0 & 17.61 \\
$11(\mathrm{CP})$ & 0 & 0 & 17.68 \\
\hline
\end{tabular}


Analysis through ANOVA indicated the mathematical model and as well as statistical significance of each evaluated factor (independent variables) for a $95 \%$ confidence interval. These results are displayed in Table 4 and figure 1 . In Table 4 it can be observed that linear variables corresponding to $\mathrm{HH}$ and yeast extract are statistically significant. With respect to quadratic variables, only the one associated to $\mathrm{HH}$ is significant, being it the most relevant variable regarding lactic acid production. Hence, the quadratic variable associated to the yeast extract is not included in the mathematical model (Equation 1). However, interaction between the two factors, which is marginally significant $(0.06)$, is included.

$$
\text { Lactic acid }(g / L)=17.76+1.85 * x-0.59 * x^{2}+0.46 * y-0.41 * x * y
$$

Where:

$\begin{array}{ll}\mathrm{x} & \text { Hemicellulose hydrolysate }(\%)(\mathrm{v} / \mathrm{v}) \\ \mathrm{y} & \text { Yeast extract }(\mathrm{g} / \mathrm{L})\end{array}$

Table 4. Analysis of variance (ANOVA) for lactic acid production after 48h.

\begin{tabular}{lccccc}
\hline Factors & Sum of squares & GL & Median square & $F$ & $P$ \\
\hline (1) Hydrolysate(L) & 27.384 & 1 & 27.384 & 610.861 & 0.002 \\
Hydrolysate (Q) & 1.986 & 1 & 1.986 & 44.301 & 0.022 \\
$\begin{array}{l}\text { (2) Yeast extract } \\
\text { (L) }\end{array}$ & 1.693 & 1 & 1.693 & 37.759 & 0.025 \\
Yeast extract (Q) & 0.031 & 1 & 0.031 & 0.687 & 0.494 \\
1L x 2L & 0.684 & 1 & 0.684 & 15.260 & 0.060 \\
lack of fit & 0.715 & 3 & 0.238 & 5.319 & 0.162 \\
Pure error & 0.090 & 2 & 0.045 & & \\
Total & 32.932 & 10 & & & \\
\hline
\end{tabular}

The coefficient of determination $\left(\mathrm{R}^{2}=0.975\right)$ indicates a high significance of the model, which is corroborated by a lack of fit that is not significant. Only $2.5 \%$ of the total variance cannot be predicted by the model. Overall, these results indicate that model fits well experimental data.

Response Surface (figure 2), which relates the independent variables ( $\mathrm{HH}$ and yeast extract concentrations) to the dependent variable (concentration of produced lactic acid), was obtained through model regression. For purposes of optimization, the following parameters were applied: increase of lactic acid concentration, increase of HH proportion with respect to culture medium and decrease in the levels of yeast extract. A proportion of $40 \%$, along with $5 \mathrm{~g} / \mathrm{L}$ of yeast extract were indicated as the optimal conditions. These conditions were then validated and result is shown in Table 5. 


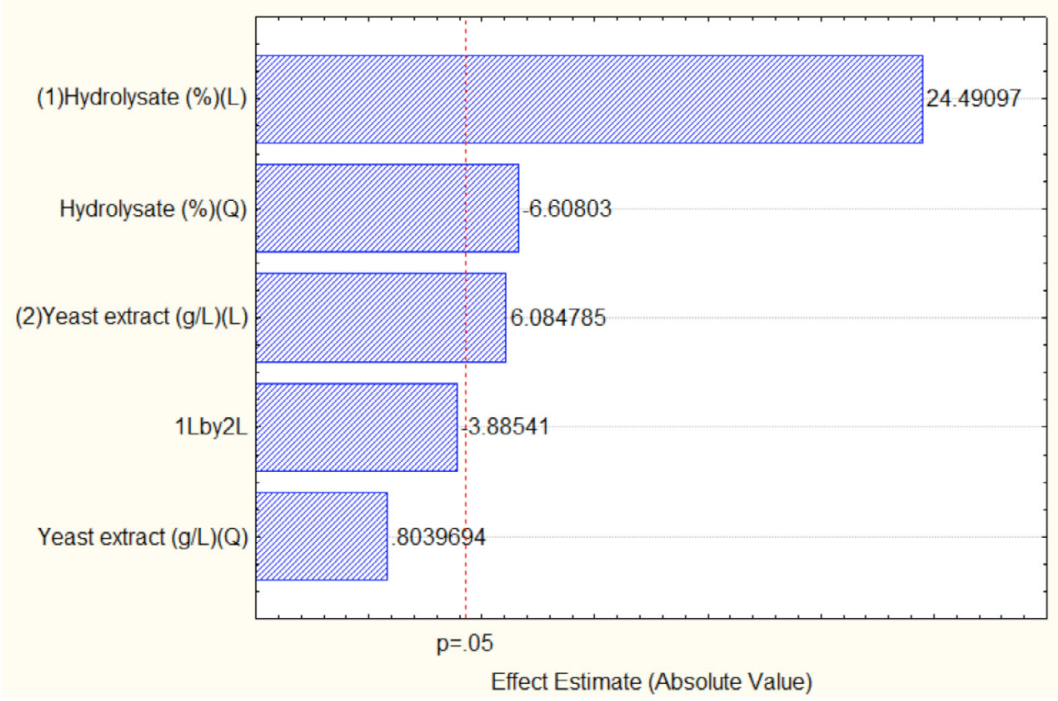

Figure 1. Pareto chart for lactic acid production (CCRD design) by Lactobacillus pentosus.

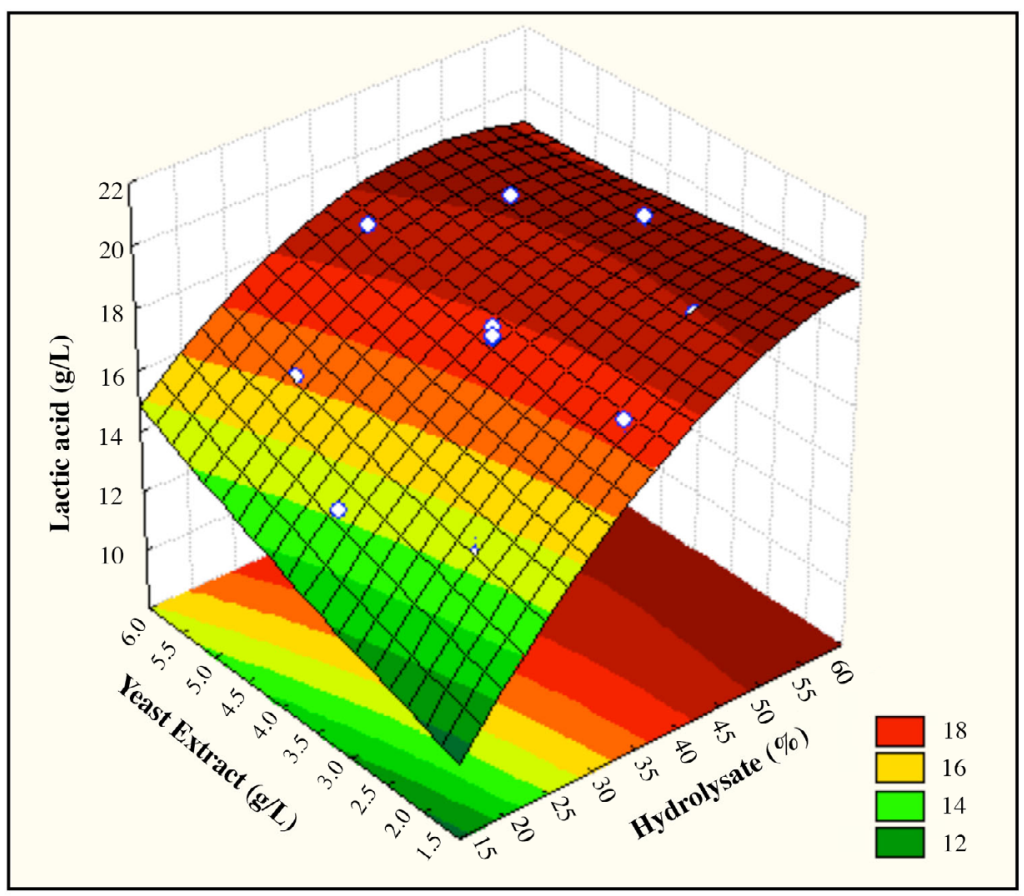

Figure 2. Response Surface for lactic acid production after $48 \mathrm{~h}$ of fermentation by Lactobacillus pentosus. 
Table 5. Validation of predicted model for lactic acid production after $48 \mathrm{~h}$ by L. pentosus.

\begin{tabular}{lcccc}
\hline \multirow{2}{*}{ Factor } & \multicolumn{2}{c}{ Limits } & Predicted value & Experimental result \\
& $-95 \%$ & $+95 \%$ & & \\
\hline Lactic acid $(\mathrm{g} / \mathrm{L})$ & 18.12 & 19.60 & 18.86 & $19.17 \pm 1.88$ \\
\hline
\end{tabular}

As it can be observed from Table 5, experimental result is within the predicted limits for a $95 \%$ confidence interval, which validates the mathematical model, as well as the optimization. Regarding lactic acid production, $19.17 \mathrm{~g} / \mathrm{L}$ was produced in $48 \mathrm{~h}$, with 0.80 $\mathrm{g} / \mathrm{g}$ of yield and volumetric productivity of $0.40 \mathrm{~g} /(\mathrm{L} \cdot \mathrm{h})$. Moreover, $1 \mathrm{~g} / \mathrm{g}$ is the maximum theoretical yield to lactic acid production from xylose, meaning the optimization in this work reach a fermentation efficiency of $80 \%$ in serum bottle (De Oliveira, Komesu, Rossell \& Maciel Filho, 2018). In addition, the presence of HMF, furfural, and acetic acid (from $\mathrm{HH}$ ) did not inhibit production of lactic acid by L. pentosus ATCC 8041, so it was unnecessary to detoxify the $\mathrm{HH}$ prior to the fermentation step. Thus, results indicate that $\mathrm{HH}$ stands as potential carbon source with application in the industrial production of lactic acid.

Previously, Pejin et al. (2018) evaluated industrial by-products such as brewer's spent grain (BSG) hydrolysate, malt rootlets extract (MRE) and soybean meal extract (SME) for L-(+) lactic acid production by L. rhamnosus ATCC 7469. They observed the addition of MRE and SME increased the concentration of free amino nitrogen (FAN) and essential minerals (Fe, $\mathrm{Mg}, \mathrm{Mn}$, and $\mathrm{Zn}$ ), which had a positive effect on the fermentation. In batch fermentation, the highest lactic acid concentration (25.73 $\mathrm{g} / \mathrm{L})$, yield $(86.31 \%)$, and volumetric productivity $(0.95 \mathrm{~g} /(\mathrm{L} \cdot \mathrm{h}))$, were obtained with the addition of $50 \%$ MRE.

Liu et al. (2018) investigated the utilization of other residue: cheese whey powder (CWP) by Lactobacillus bulgaricus CGMCC 16970. To fully utilize proteins in CWP, different proteases were selected to hydrolyze CWP, and the highest D-lactic acid concentration was obtained using neutral protease pretreated CPW as substrate. Then $70.70 \mathrm{~g} / \mathrm{L}$ D-lactic acid with an average productivity of $1.47 \mathrm{~g} /(\mathrm{L} \cdot \mathrm{h})$ was obtained from batch fermentation in biorreactor with yeast extract supplementation.

According to Es et al. (2018), genetic and metabolic engineering and improving novel techniques such as cell recycle systems and simultaneous saccharification, will lead engineered microorganisms to produce lactic acid with increased concentration, yield, and productivity. Which corroborating with De Oliveira, Komesu, Rossell \& Maciel Filho (2018), they said genetic engineering tools are developing quickly, focusing on creating more resistantand productive microorganisms. Lactic acid production promises to be one of the sectors with more innovation in the near future.

\section{CONCLUSION}

To sum up, at optimal conditions, after $48 \mathrm{~h}$ of fermentation $19.17 \mathrm{~g} / \mathrm{L}$ of lactic acid were produced using hemicellulose hydrolysate as carbon source. This result 
corresponds to a volumetric productivity of $0.40 \mathrm{~g} /(\mathrm{L} \cdot \mathrm{h})$ and $80 \%$ of fermentation efficiency. Hence, findings of this work demonstrate that hemicellulose hydrolysate, obtained from dilute acid pretreatment of sugarcane bagasse, is a promising carbon source for lactic acid production presenting efficient xylose consumption.

\section{ACKNOWLEDGEMENTS}

The authors would like to thank Universidad de Costa Rica for scholarship and other financial supports.

\section{REFERENCES}

Abdel-Rahman, M. A., Tashiro, Y., \& Sonomoto, K. (2011). Lactic Acid Production from Lignocellulose-Derived Sugars Using Lactic Acid Bacteria: Overview and Limits. J. of biotechn. 156(4), 286-301.

Amin, F. R., Khalid, H.,Zhang, H., u Rahman, S., Zhang, R., Liu, G., \& Chen, C. (2017). Pretreatment Methods of Lignocellulosic Biomass for Anaerobic Digestion. AMB Expr. 7(1), 72.

Betancur, G.J. \& Pereira Jr, N. (2010). Sugarcane Bagasse as Feedstock for Second Generation Ethanol Production: Part I: Diluted Acid Pretreatment Optimization, Elect. J. Biotechnol. (13), 10-11.

Chandel, A. K., Singh, O. V., \& Rao, L. V. (2010). Biotechnological Applications of Hemicellulosic Derived Sugars: State-of-the-Art. In Sustainable Biotechnology. Springer Netherlands, 63-81.

Chandel, A. K., da Silva, S. S., \& Singh, O. V. (2011). Detoxification of Lignocellulosic Hydrolysates For Improved Bioethanol Production. In Biofuel Production-Recent Developments and Prospects. InTech, 225-246.

Deshavath, N. N., Mohan, M., Veeranki, V. D., Goud, V. V., Pinnamaneni, S. R., \& Benarjee, T. (2017). Dilute Acid Pretreatment of Sorghum Biomass to Maximize the Hemicellulose Hydrolysis With Minimized Levels of Fermentative Inhibitors for Bioethanol Production. 3 Biotech, 7(2), 139.

De Oliveira, R. A., Komesu, A., Rossell, C. E., Maciel Filho, R. (2018). Challenges and Opportunities in Lactic Acid Bioprocess Design-From Economic to Production Aspects. Biochem. Eng. J. (133), 219-239.

Eş, I., Khaneghah, A. M., Barba, F. J., Saraiva, J.A., Sant'Ana, A. S., Hashemi, S. M. (2018). Recent Advancements in Lactic Acid Production-a Review. Food Resear. Int. (107), 763-770.

Garde, A., Jonsson, G., Schmidt, A. S., \& Ahring, B. K. (2002). Lactic Acid Production From Wheat Straw Hemicellulose Hydrolysate by Lactobacillus Pentosus and Lactobacillus Brevis. Bioresour. Technol. 81(3), 217-223.

Gonzales, R. R., Sivagurunathan, P., \& Kim, S. H. (2016). Effect of Severity on Dilute Acid Pretreatment of Lignocellulosic Biomass and the Following Hydrogen Fermentation. Int. J. of Hydrog. Ener. 41(46), 21678-21684.

Hendriks, A. T. W. M., \& Zeeman, G. (2009). Pretreatments to Enhance the Digestibility of Lignocellulosic Biomass. Bioresour. Technol. 100(1), 10-18. 
Jönsson, L. J., \& Martín, C. (2016). Pretreatment of Lignocellulose: Formation of Inhibitory by-Products and Strategies For Minimizing Their Effects. Bioresour. Technol, (199), 103-112.

Kumar, P., Barrett, D. M., Delwiche, M. J., \& Stroeve, P. (2009). Methods for Pretreatment of Lignocellulosic Biomass For Efficient Hydrolysis and Biofuel Production. Industr. \& Eng. Chemist. Resear. 48(8), 3713-3729.

Liu, P., Zheng, Z., Xu, Q., Qian, Z., Liu, J., Ouyang, J. (2018). Valorization of Dairy Waste For Wnhanced D-lactic Acid Production at Low Cost. Proc. Biochem. (71), 18-22.

Patel, M., Ou, M., Ingram, L. O., \& Shanmugam, K. T. (2004). Fermentation of Sugarcane Bagasse Hemicellulose Hydrolysate to L (+)-lactic Acid by a Thermotolerant Acidophilic Bacillus sp. Biotechnol. Lett. 26(11), 865-868.

Pejin, J., Radosavljević, M., Pribić, M., Kocić-Tanackov, S., Mladenović, D., Djukić-Vuković, A., Mojović, L. (2018). Possibility of L-(+)-lactic Acid Fermentation Using Malting, Brewing, and Oil Production by-Products. Wast. Managem. (79), 153-63.

Wischral, D., Arias, J. M., Modesto, L. F., Passos, D. F., Pereira Jr, N. (2018). Lactic Acid Production from Sugarcane Bagasse Hydrolysates by Lactobacillus pentosus: Integrating Xylose and Glucose Fermentation. Biotechnol. Prog. 1-9.

Xavier, M. C. A., Coradini, A. L. V., Deckmann, A. C., \& Franco, T. T. (2017). Lipid Production From Hemicellulose Hydrolysate and Acetic Acid by Lipomyces Starkeyi and the Ability of Yeast to Metabolize Inhibitors. Biochem. Eng. J. (118), 11-19. 